\title{
A High Step Up Hybrid Switch Converter Connected With PV Array For High Voltage Applications
}

\author{
Amritashree \\ Department of Electrical and Electronics Engineering, Biju Pattnaik University of \\ Technology, Rourkela, Odisha
}

\begin{abstract}
This paper presents a step up DC-to-DC converter with hybrid switch capacitor technique having high voltage conversion ratio with small switch voltage stress. The converter is suitable for the applications where high voltage conversion is required. The proposed DC-DC converter has low voltage ratted MOSFET switch and is connected to PV array to get high output voltage at small duty ratios. Hence it has high efficiency. The principles of operations and the theoretical analysis are presented in this paper. All the simulations are done in MATLAB-SIMULINK Environment and results were obtained with voltage conversion ratio of 4.9 .
\end{abstract}

\section{KEYWORDS}

DC-DC converters; voltage conversion ratio ; duty ratio.

\section{INTRODUCTION}

The year 1973 is known as the first oil crisis of the world. Oil prices increased fourfolds which resulted in the need to use alternate source of energy like solar, wind, biomass etc. Attempts were made by scientists for utilising these alternate source of energy as these resources can be renewed by nature again and again. Also the supply of these alternate source does not depends on the rate of their consumption. Many applications require high step-up, DC-to-DC converters. Typical applications are renewable energy systems, fuel cells, and uninteruptible power supply (UPS) system [1 ].The duty ratio for conventional step up converter for high output voltage is high . Converters with high voltage conversion ratios have less efficiency and high switch voltage stress. So research should be done to increase efficiency and to reduce switch voltage stress.

When talking about the conventional boost converter having high output voltage needs MOSFET with which voltage ratings is high. Such MOSFET has high on- resistance as a result the size, cost and conduction losses increases which is the reason for decrease of efficiency of the conventional boost converter [2]. In a conventional boost converter, a switch- capacitor circuit has been inserted to increase the efficiency and voltage conversion ratio[3]. The switch capacitor circuit basically consist of a controlled switch, two diodes and two capacitors. This converter has many advantage, namely low switch voltage stress and better efficiency. Due to low switch voltage stress, uses MOSFET with low voltage rating. A switch capacitor technique has been used to have low voltage stress on the active switch. The circuit then uses low on resistance and smaller switching periods. Thus, decreasing the conduction as well as switching losses [4], [5]. A switch 
capacitor is inserted in a boost converter to increase the efficiency and to achieve a high conversion ratio. The proposed converter provide high voltage gain with low duty ratio [6].

The cascade boost converter in [7] can supply high output voltage with relatively high efficiency. The major drawback of this converter is the complexity and higher cost due to the use of two dcdc converters. Futher to achieve high voltage gain, converters with coupled inductors [8]-[13] are proposed but their efficiency are reduced due to losses associated with leakage inductors. Moreover, these converters with coupled inductor requires high voltage ratted switch and also suffers from EMI problems. Use of active-clamp circuit [14],[15] can recycle the leakage energy and can reduce the main switch voltage stress. But this can be achieved at the expense of circuit complexity as well as this active-clamp circuit has extra losses related to the clamp circuit.

\section{OPERATION OF SWITCHED CONVERTER WITH HIGH BOOST RATIO}

\subsection{Hybrid switch converter}

This hybrid switch converter is based on use of switching cell. The switching cells combines the idea of two switching cells.

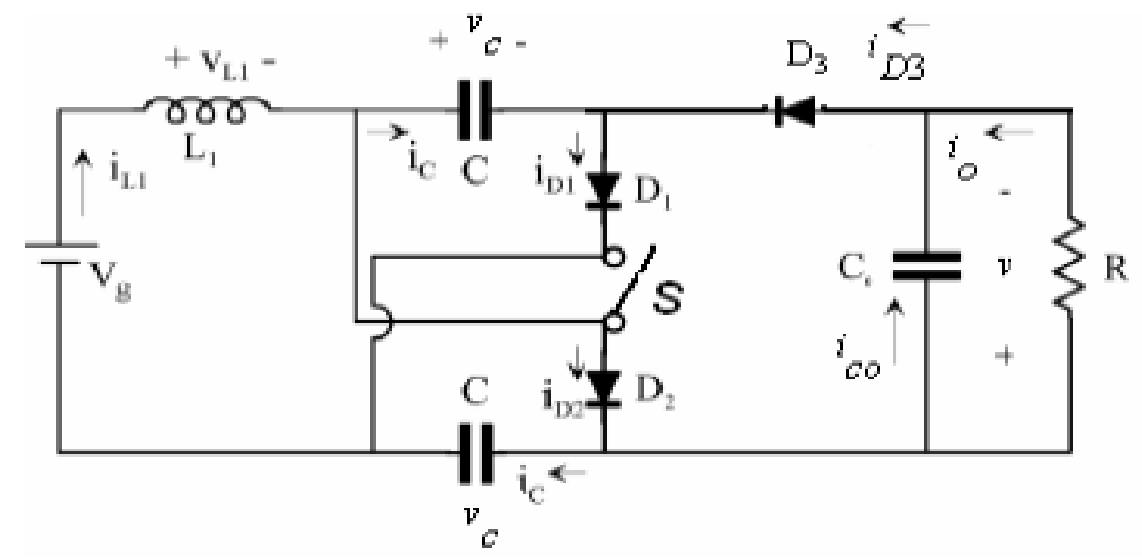

\subsection{Modes of operations}

Figure 1- Switched Boost converter.

The converter is operating in steady state and it is assumed that during one switching cycle, all the components are ideal and there is negligible voltage ripple and inductor current ripple in the capacitors and inductors respectively.

Interval $1\left[0, t_{1}\right]$, Figure $2:$ At time $t=t_{1}$, switch $S$ is $O N$. The inductor $L_{1}$ is charged by input voltage $\mathrm{V}_{\mathrm{g}}$. Due to negative voltage " $-\mathrm{V}_{\mathrm{c}}$ " of the capacitors, diodes $\mathrm{D}_{1}$ and $\mathrm{D}_{2}$ are reversed biased and $\mathrm{D}_{3}$ is forward biased .The voltage across the capacitors ' $\mathrm{C}$ ' are equal. The energy stored in the capacitors ' $\mathrm{C}$ ' is being transferred to the load and the output capacitor ' $\mathrm{C}_{\mathrm{o}}$ ' is charged during this interval.

Interval 2[ $\left.t_{1}, T_{s}\right]$, Figure 3:At time $t=t_{1}$, switch $S$ is OFF. Diodes $D_{1}$ and $D_{2}$ are forward biased and diode $\mathrm{D}_{3}$ is reversed biased thus providing path for input and output inductor current. The two capacitor ' $\mathrm{C}$ ' are in parallel and they are charged equally. The energy stored in the output capacitor during the time when switch $\mathrm{S}$ is $\mathrm{ON}$ is being transferred to load. 
International Journal on Information Theory (IJIT),Vol.4, No.2, April 2015

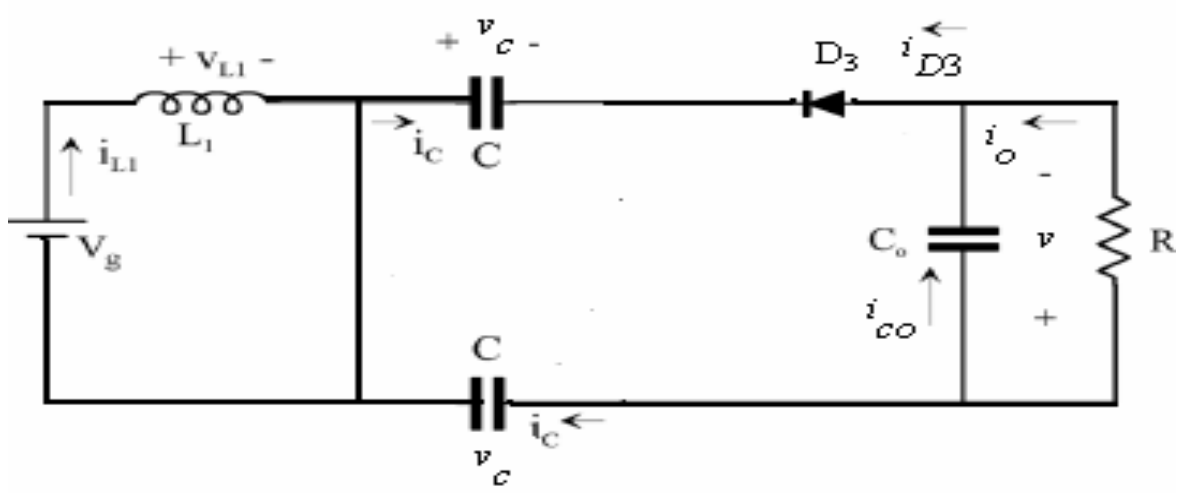

Figure 2- First switching interval

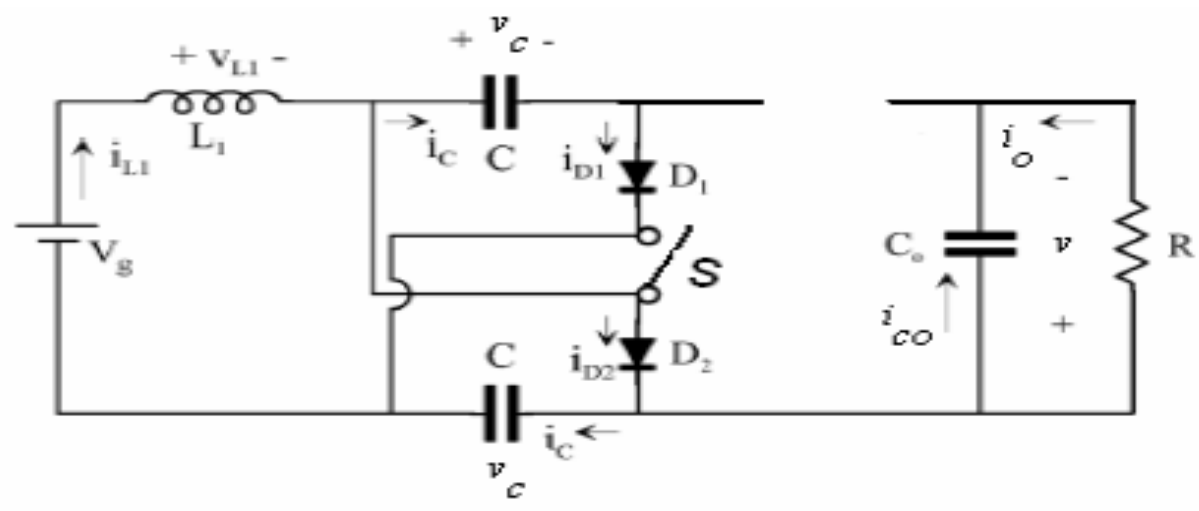

Figure 3- Second switching interval

For first switching interval $(0 \leq \mathrm{t} \leq \mathrm{DTs})$

$v_{L 1}=L_{1} \frac{d i_{L 1}}{d t}=V_{g}$

$i_{C O}=C_{C O} \frac{d v}{d t}=\frac{(1-D)}{2 D} i_{L 1}-i_{0}$

$i_{C}=C \frac{d v_{c}}{d t}=-\frac{D^{\prime}}{2 D C} I_{L 1}$

For second switching interval (DTs $\leq \mathrm{t} \leq \mathrm{Ts}$ )

$$
\begin{aligned}
& V_{L 1}=L_{1} \frac{d i_{L 1}}{d t}=V_{g}-v_{c} \\
& i_{c o}=C_{c o} \frac{d v}{d t}=-i_{o} \\
& i_{c}=\frac{i_{L 1}}{2}
\end{aligned}
$$




\subsection{Converter voltage conversion ratio and switch voltage stress}

$$
M=\frac{v}{V_{g}}=\frac{2}{1-D}
$$

The normalized MOSFET switch stress

$$
M_{S w}=\frac{1}{2}
$$

The voltage stress of the MOSFET switch is half of the output voltage. So the voltage stress of the proposed topology is less than the conventional Cuk converter. The voltage stress is independent of the duty cycle. Using principles of capacitor charge balance following information is obtained:

$$
I_{L 1}=\frac{2 I_{0}}{D^{\prime}}
$$

Where $D^{\prime}=1-D$

\subsection{Inductor design}

The time interval during first switching interval, inductor current ripple ' $\Delta i_{L 1}$ ' is equal to

$$
L_{1}=\frac{V_{g}}{2 \Delta i_{L 1}} D T_{S}
$$

\subsection{Capacitor design}

The size of capacitor ' $\mathrm{C}$ ' depends on the voltage ripple in the capacitor. So, for smaller ripple the value of capacitance is large. The capacitor voltage ripple can be determined by using exequation (3).

$$
C=\frac{I_{0} T_{S}}{2 \Delta v_{c}}
$$

\subsection{Output capacitor design}

The output capacitor ' $\mathrm{C}_{\mathrm{o}}$ ' voltage ripple can be determined by using equation (5).

$$
C_{0}=\frac{I_{0}(1-D) T_{S}}{2 \Delta v}
$$

\subsection{Design of PV array}

A solar PV array is modelled using 36 solar cells. With insolation of $1000 \mathrm{~W} / \mathrm{m}^{2}$ an output voltage of $19.29 \mathrm{~V}$ is obtained. The open circuit voltage, Voc is $19.29 \mathrm{~V}$, short circuit current is $4.75 \mathrm{~A}$ and output power is $75 \mathrm{~W}$ 


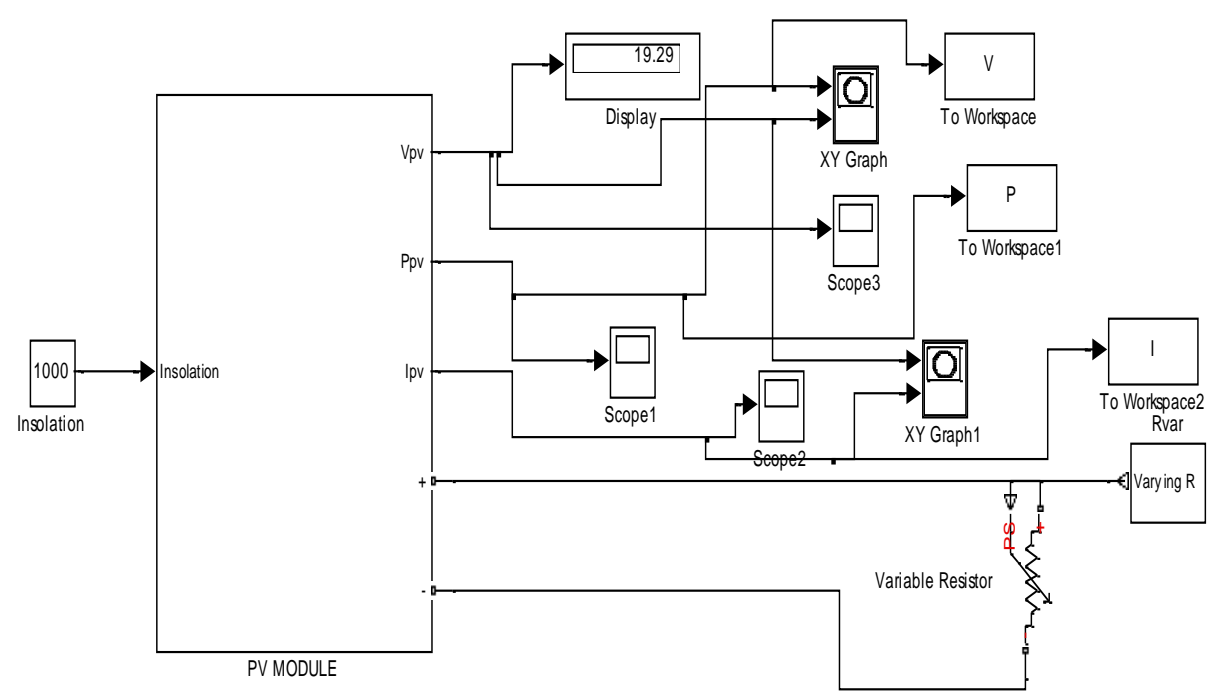

Figure 4 - Simulation diagram of PV module.

\subsection{Simulation diagram and results}

The proposed switch converter is simulated using MATLAB SIMULINK environment.

\subsubsection{Converter with DC source}

The proposed dc-dc converter is connected with simple dc source .

Figure 5 - Simulation diagram of switch converter with DC source.

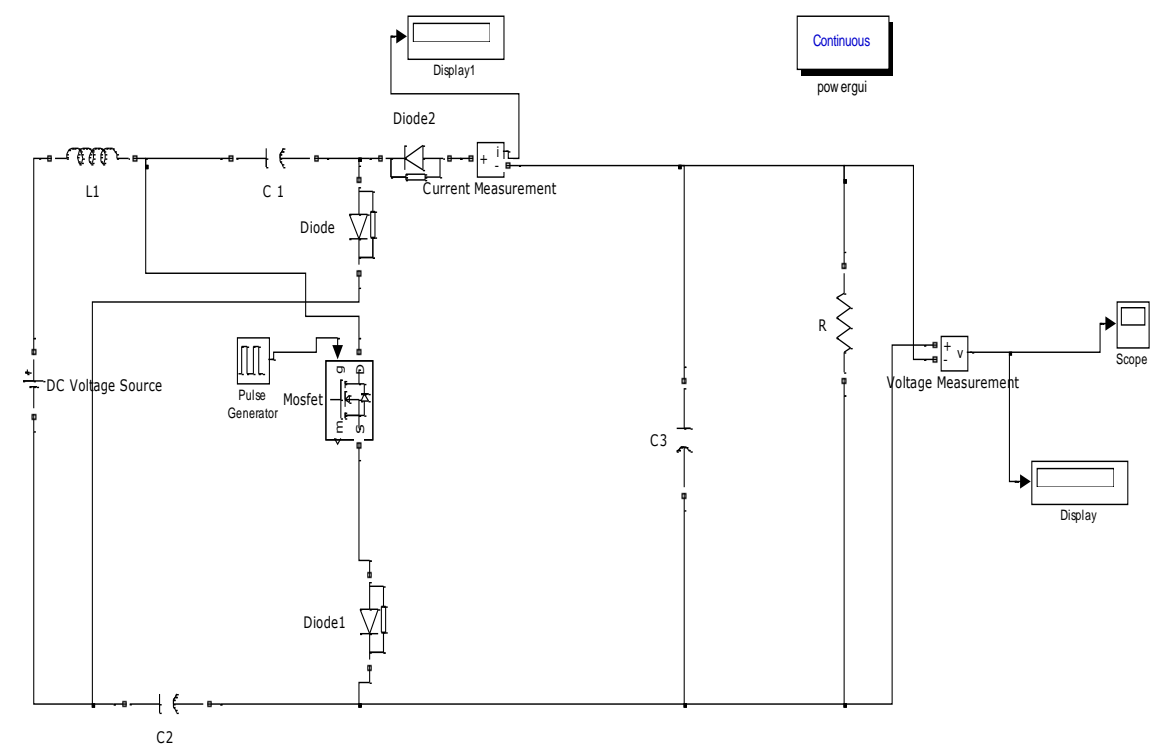




\subsubsection{Switch converter with $P V$ array}

The switch converter is connected to PV array. Thirty six solar cells are used to design the PV module connected to the proposed converter [16].

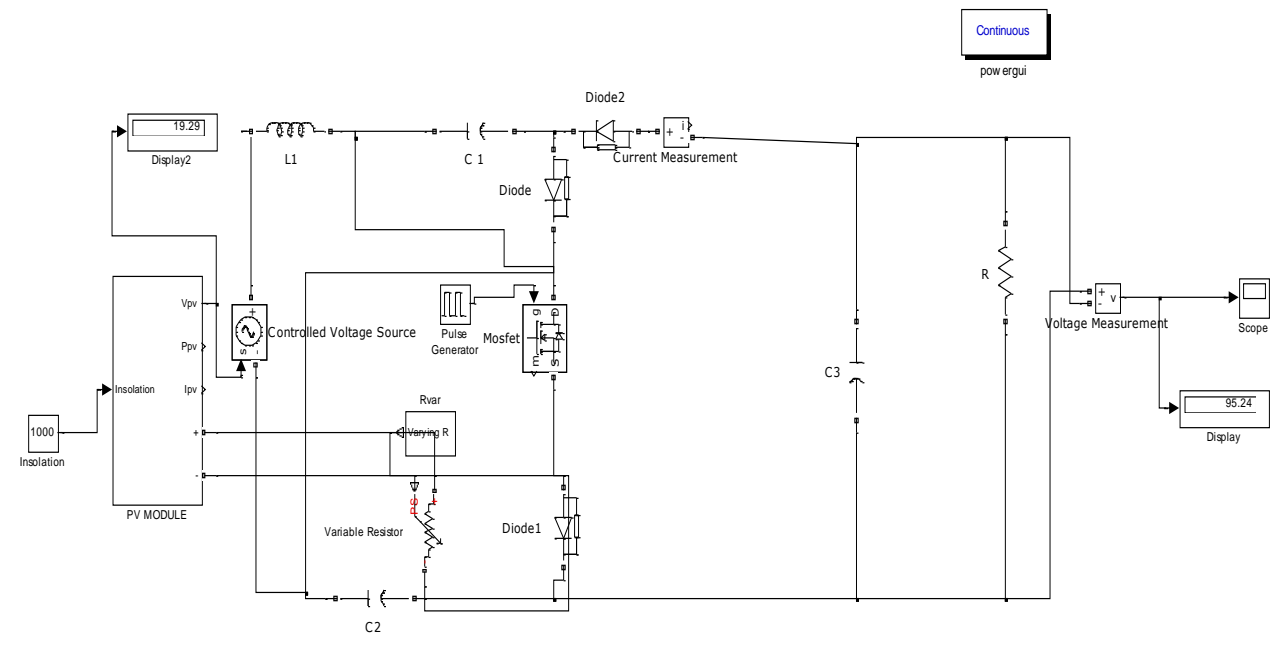

Figure 6 - Simulation diagram of the converter connected with PV array.

\subsubsection{Result of the converter with DC source and PV array}

A switch converter was designed for high voltage application with low input voltage source like PV array. At first this converter was connected with low voltage DC source, with a DC input voltage of $20 \mathrm{~V}$ a output voltage of $100.6 \mathrm{~V}$ is obtained from the switch converter whereas when the switch converter is connected with the PV array we get an output voltage of $19.29 \mathrm{~V}$ from PV array and which is the input to the switched converter from which we get a output voltage of 95.24V. The switching frequency is $20 \mathrm{KHz}$. The series capacitance $\mathrm{C}_{1}, \mathrm{C}_{2}$ is $0.035 \mu \mathrm{F}$. The input inductor $\mathrm{L} 1$ is set to $500 \mu \mathrm{H}$ to ensure continuous conduction mode and the output capacitor were set to $150 \mu \mathrm{F}$.

The simulated waveforms are shown in Figure 7 and Figure 8. It is understood from the simulation result that the proposed hybrid switch converter gives high voltage at a duty ratio of 0.6 . Hence the hybrid switch converter has high efficiency with smaller duty ratio.

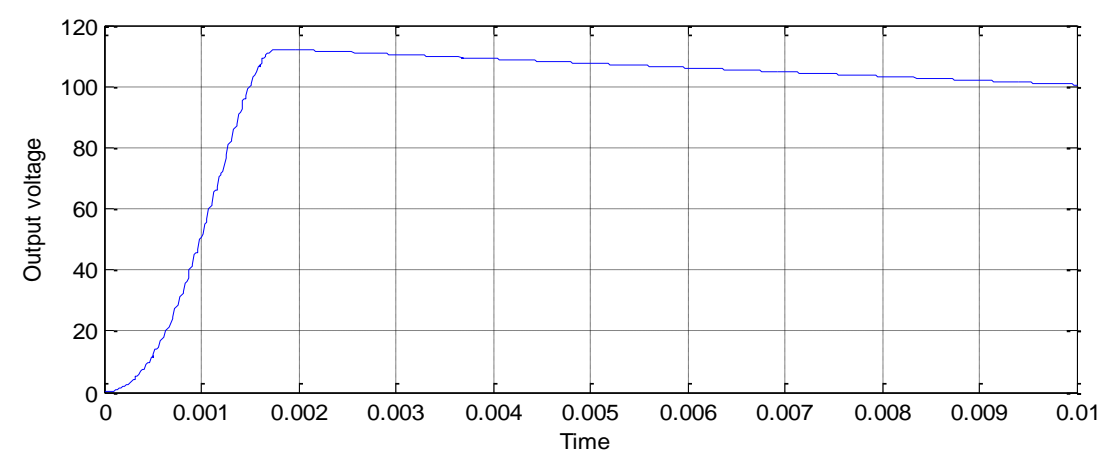

Figure 7- Simulation result of switch converter with DC source. 
International Journal on Information Theory (IJIT),Vol.4, No.2, April 2015

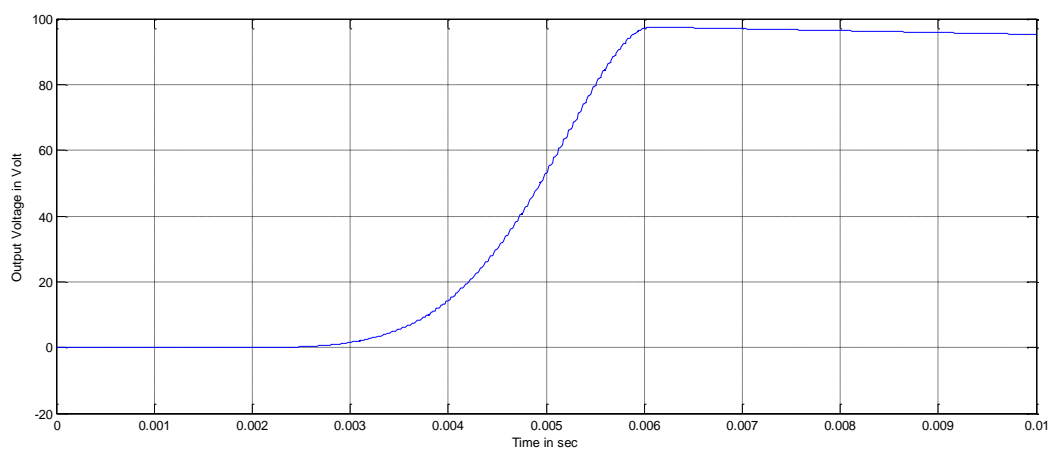

Figure 8 - Simulation result of switch converter with PV array.

\subsubsection{PV array I-V characteristic}

Thirty six solar cells are connected in series inside the PV array to get additive voltage. The short circuit current Isc is $4.75 \mathrm{~A}$ and open circuit voltage $\mathrm{V}_{\text {oc }}$ is $19.29 \mathrm{~V}$.

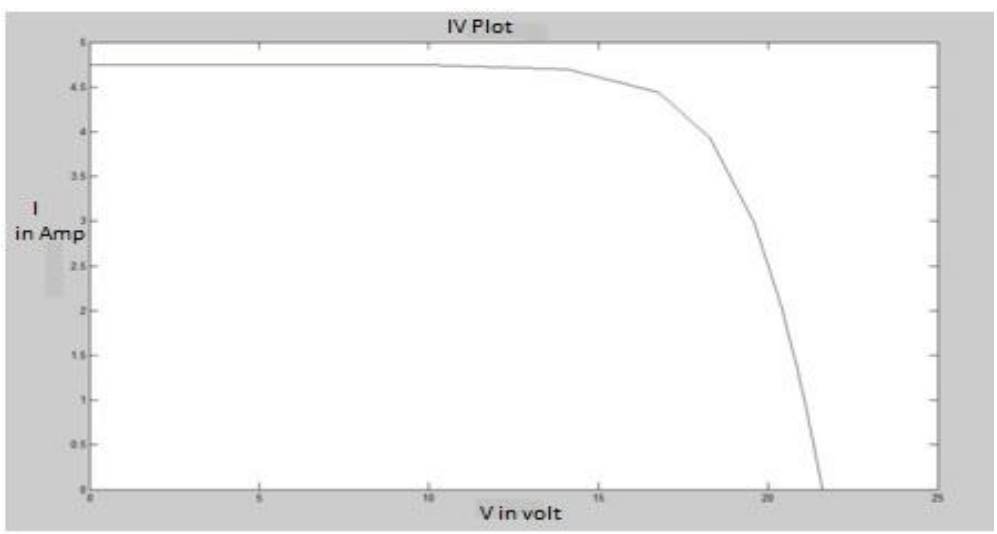

Figure $9-\mathrm{I}-\mathrm{V}$ characteristic of solar array.

\subsubsection{PV array $P-V$ characteristic}

The output power from the PV module is $75 \mathrm{~W}$.

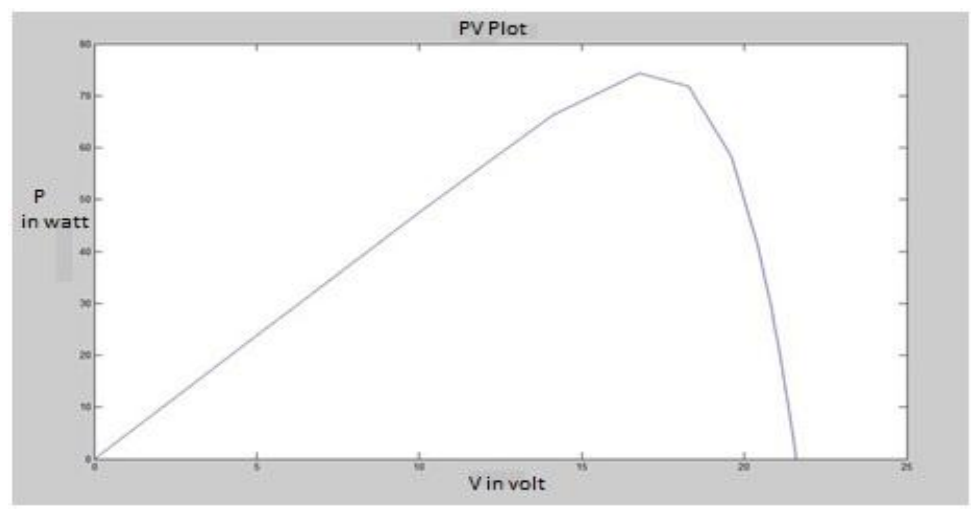

Figure $10-\mathrm{P}-\mathrm{V}$ characteristic of solar array. 


\subsubsection{Tables}

Table 1. Output voltage of the converter with change in insolation

\begin{tabular}{|c|c|c|c|}
\hline SL. NO. & Insolation $\left(\mathrm{W} / \mathrm{m}^{2}\right)$ & $\begin{array}{c}\text { Output of PV array } \\
(\mathrm{V})\end{array}$ & $\begin{array}{c}\text { Output of the } \\
\text { converter }(\mathrm{V})\end{array}$ \\
\hline 1. & 1000 & 19.29 & 95.24 \\
\hline 2. & 900 & 18.20 & 87.96 \\
\hline 3. & 800 & 16.21 & 69.32 \\
\hline 4. & 700 & 14.84 & 66.95 \\
\hline 5. & 600 & 12.79 & 49.73 \\
\hline 6. & 500 & 10.68 & \\
\hline
\end{tabular}

\section{Conclusions}

This study has successfully developed a new class of single switch step up dc-dc converter with simple topologies. The analysis of different converters has resulted in a new switching cell. The new switching cell combines the idea of two switching cells presented in two different papers. The insertion of new switching cell in a conventional Cuk converter has resulted in hybrid switch converter. The proposed converter used a hybrid switched capacitor technique for achieving high voltage conversion ratio at small duty ratio. The operation of the proposed converters was analyzed for continuous mode. The proposed topology has better advantages over conventional DC-to-DC converters with respect to high efficiency, high voltage conversion ratio and simplicity of design. Simulation and experimental results show full agreement with theoretical analysis. Finally, the proposed concept can be used easily in Power Conversion Systems in order to satisfy high- voltage demands. reduced switch voltage stress.

\section{ACKNOWLEDGEMENTS}

I would like to thank Prof. Lopamudra Mitra for her support and guidance for completing this project and writing this paper.

\section{REFERENCES}

[1] Macros prudente, Luciano L. Pfitscher, Gustavo Emmendoerfer, "Voltage Multiplier Cells Applied to Non-Isolated DC-DC Converters,'IEEE Transactions on Power Electronics, Vol.23, No. 2, March 2008.

[2] Esam H. Ismail and Ahmad J. Sabzali, "High Conversion Ratio DC-DC Converters With Reduced Switch Stress" IEEE Transactions on circuits and System-I: Regular Papers, Vol.55, No.7, August 2008.

[3] O.Abutbul,A.Gherlitz,Y.Berkovich,and A.Ioinovici, "Step-up switching mode converter with high voltage gain using a switched-capacitor circuits,'IEEE Transaction Circuits and Systems Vol. 50, no. 8, pp. 1098-1102, 2003. 
[4] Q. Zhao, F. Tao, and F. C. Lee, "High-efficiency, high step-up dc-dc converters," IEEE Trans. Power Electron., vol. 18, pp. 65-73, Jan. 2003.

[5] Q. Zhao, F.Tao, Y. Hu and F.C. Lee ,“ Active-clamp dc/dc converters using magnetic switches,” in proc. IEEE Applied Power Electron. Conf2001, Vol.2,pp. 946-952.

[6] Q. Zhao and F.C. Lee, " High performance coupled- inductor dc-dc converters," in proc. IEEE Appl. Power Electon. Conf. ,2003,Vol. 1,pp. 109-113.

[7] L. Huber and M.M. Javanovic, “ Adesign approach for server power supplies for networking,” in proc. IEEE Appl. Power Electron. Conf., 2000, pp. 1163-1169.

[8] E. Rodriguez, D. Abud, and J. Arua, "A novel single-stage single-phase dc uninteruptible power supply with power-factor correction,” IEEE Trans. Ind. Electron., vol. 46, pp. 1137-1147, Dec 1999.

[9] K.W. Ma and Y.S. Lee, “ An integrated flyback converter for dc uninterruptible power supply," IEEE Trans. Power Electron., vol.11, no.2, pp. 318-327, Mar. 1996.

[10] J. Wang, W.G. Dunford, and K. Mauch, " A comparision of modified boost converters with continuous inductor current mode and ripple free input current with conventional converters," in proc. IEEE Ind. Appl. Conf., New York, 1996, pp. 878-885.

[11] D.K.W. Cheng, X.C. Liu, and Y.S. Lee, "A new improved boost converter with ripple free input current using coupled inductors," in proc. IEE Int. Conf. Power Electron. Variable Speed Drives, London, U.K., 1998, PP. 592-599.

[12] J. Wang, W. Dunford, and K.Mauch, "Modified boost converter with continuous inductor current mode and ripple free input current," in proc. IEEE Power Electron. Specialists conf.,1996, pp. 390396.

[13] Q. Zhao, F. Tao, and F.C. Lee, “ A front end dc/dc converter for network server applications," in proc. IEEE Power Electron. Specialists Conf. 2001, pp. 1535-1539.

[14] R. Watson, F.C. Lee, and G.C. Hua, "Utilisation of an active-clamp circuit to achieve soft switching in flyback converters,” IEEE Trans. Power Electron., vol.11, pp. 162-169, Jan 1996.

[15] C.T. Choi, C.K. Li, and S.K. Kok, " Modelling of an active- clamp discontinuous conduction mode Flyback converter under variation of operating condition,” in proc. IEEE PEDS Conf., 1999, pp. 730733.

[16] M.G. Villalva, J.R. Gazoli, and E.R. Filho, "Comprehensive approach to modelling and simulation of photovoltaic arrays," IEEE Transaction on Power Electronics, vol. 24, no. 5, pp. 1198-1208, May 2009.

\section{Author}

Amritashree was born in 1990. Now she is doing her M. Tech from Silicon Institute of Technology under Biju Pattnaik University of Technology, Odisha. Her research area is application of DC-DC Converters for utilising renewable energy sources.

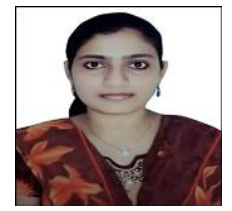

